\title{
Tanzanian childhoods: street children's narratives of 'home'
}

Article

Accepted Version

Evans, R. (2004) Tanzanian childhoods: street children's narratives of 'home'. Journal of Contemporary African Studies, 22 (1). pp. 69-92. ISSN 1469-9397 doi:

https://doi.org/10.1080/0258900042000179616 Available at https://centaur.reading.ac.uk/24444/

It is advisable to refer to the publisher's version if you intend to cite from the work. See Guidance on citing.

To link to this article DOI: http://dx.doi.org/10.1080/0258900042000179616

Publisher: Taylor \& Francis

All outputs in CentAUR are protected by Intellectual Property Rights law, including copyright law. Copyright and IPR is retained by the creators or other copyright holders. Terms and conditions for use of this material are defined in the End User Agreement.

\section{www.reading.ac.uk/centaur}

\section{CentAUR}

Central Archive at the University of Reading

Reading's research outputs online 


\title{
Tanzanian Childhoods: Street Children's Experiences of 'Home'
}

\section{Ruth M.C. Evans}

\begin{abstract}
This article discusses Tanzanian street children's narratives of their home environments and their experiences of family life. Based on findings from childfocused ethnographic research, I identify the salient factors influencing children's decisions to leave their immediate household to seek a living independently within the urban environment. These include chronic poverty and social marginalisation, negative features of the social construction of childhood, such as corporal punishment and the conflict between 'work' and 'play', underlying gender inequalities, children's experiences within diverse household structures, and rural-urban migration. My research refutes assumptions about street children as being predominantly 'orphans' or 'abandoned', and suggests that a complex myriad of factors influence children's decisions to leave home. Children are very often making a rational choice of one lifestyle over another, in response to difficult home environments and oppressive adult-child relations.
\end{abstract}

\section{Introduction}

The visible presence of children and young people living independently on the street in towns and cities in Tanzania has greatly increased throughout the 1980s and 1990s. The economic situation and levels of national poverty in contemporary Tanzania strain the relationships between household members, and in particular, the narratives of home', Journal of Contemporary African Studies, 22 (1): 69-92. 
generational contracts between adult and children have increasingly come under pressure. The World Bank estimates that 43 per cent of the rural population and 19 per cent of the urban population live below the poverty line (Bendera, 1999: 118). The global economic recession and subsequent Structural Adjustment Programmes have been felt by both the agricultural and urban sectors, each of which is increasingly unable to provide a livelihood for most households (Koda, 1995). Koda suggests that this has led to "a great exodus of human labour from the agricultural to, predominantly, the service sector", with young girls and boys, in particular, migrating to urban areas in search of wage labour (ibid, 141). Thus, the resources available to Tanzanian children, both materially and in terms of human care, are stretched very thin.

Whilst 'street children' (1) may be the most visible category of children in especially difficult circumstances, research from many countries has shown that the portrayal of street children as homeless and 'abandoned' is not representative of the majority of their population. In Columbia, Felsman (1981) found that 61 per cent of street children had close contact with their families, returning home every day (Veale at al., 2000:135). In Latin America, 80-90 per cent of street children have contact with their families (ibid). In a study of four Ethiopian towns, Veale and Adefrisew (1993) found that fewer than 20 per cent of children regularly slept on the streets (ibid). Similarly, in Zimbabwe, Muchini and Nyandiya-Bundy (1991) found that 85 per cent of 'street youth' lived in a family at least some of the time, and in South Africa, Donal and Swart-Kruger (1994) claimed that about 90 per cent of the young people working on the streets return to their homes at night (Mufune, 2000:236). 
Green notes that in Latin America and the Caribbean, street children's own accounts of why they left home "differ strikingly from the conventional accounts of helplessness, abandonment and poverty": "There are cases of orphans or abandoned children, but for the majority, leaving for the street is a conscious choice of one life over another" (Green, 1998:64). Aptekar's fieldwork in Colombia (1988) led to his conclusion that most street children were not abandoned, a conclusion supported by Veale's $(1992 ; 1996)$ research in Sudan and Ethiopia, where children looked to the street for the fulfilment of needs that were unmet in the home (Veale et al., 2000:135). Veale reveals that for the children, managing for themselves was an escape from home, where the parents themselves were unable to provide for all: they cited less regular abuse on the street, a "greater variety of food to be gained from the street, strong friendships, and the satisfaction they got from being able to manage for themselves without having to put up with strict parental discipline" (ibid, 136). Indeed, on the basis of key research findings from empirical literature on street children in Colombia, South Africa, Brazil, Honduras, Ethiopia, Sudan, Nepal and Indonesia, Veale et al. conclude that: "Without discounting the deprivations and hazards that exist in the street, children often cite what can only be described as positive features of the street environment that offer solutions to problems in their lives at home" (ibid, 137).

Although the literature on how childhood is experienced by children in Africa, and Tanzania in particular, is sparse, there are numerous academic, government and nongovernmental studies conducted with street children in Tanzania. This discourse usually concentrates either on the characteristics of children on the street, or on the host of remedial NGOs and other institutions established to provide for their needs narratives of home', Journal of Contemporary African Studies, 22 (1): 69-92. 
(UNICEF, 1999). This paper attempts to give a more holistic analysis of children's experiences of family life and their home environments, which influenced their decisions to leave home for the street. Using empirical data from ethnographic, childfocused research with street children, I will discuss children's narratives of their home environments (2). Salient motivating factors are identified as poverty and household instability, corporal punishment, the conflict between 'work' and 'play', underlying gender inequalities and children's experiences within diverse household structures, and rural-urban migration.

The theoretical framework of the social construction of childhood will be used to analyse the ethnographic material, adopting a child-centred approach, which recognises the ethical importance of listening to children and believing their accounts (James and Prout, 1997). As Baker and Panter-Brick note, however, one must exercise caution when analysing children's (and adults') accounts of 'the past', since "in recounting a personal history, particularly one which may have been traumatic, feelings and ideas from the present may be projected on to past events in order to 'explain' them” (Baker and Panter-Brick, 2000:170). Thus, while the children's accounts have been taken at face value in this study, they can also be seen as part of the child's retrospective attempt to rationalise why they came to live and work on the streets, rather than to live within the family home. Normalising concepts of children's place at home with their family, and what children perceive as justifiable grounds (to a mzungu [European] woman) for running away from home, therefore influence their narratives. Parents' perspectives sometimes differ greatly from children's, and thus I also attempt to give some sense of parental concerns about their children and parents' responses to difficult home environments, through my conversations with parents and narratives of home', Journal of Contemporary African Studies, 22 (1): 69-92. 
observations of visits to the children's families and contact with parents at the street children centres.

\section{Poverty and household instability}

As Lockwood notes, poverty analyses often focus on income and assets in the short run, to the neglect of familial relationships (Lockwood, 1997:96). However, more recent studies have recognised the need to analyse poverty from a multidimensional perspective, linking poverty to social exclusion and social capital (ibid; Hulme and Shepherd, 2003:407). A distinction has been drawn between 'chronic poverty', when people remain poor for much of their life course and may 'pass on' their poverty to subsequent generations - termed 'intergenerational transmission of poverty'- and 'transient poverty' when people experience poverty for certain periods, but are able to move out of poverty (Hulme and Shepherd, 2003:405). This concept of chronic poverty, and the intergenerational transmission of poverty from the older generation to children is useful in the context of this study. Lockwood suggests that impoverishment can be conceptualised as a long-run spiral, which involves not only economic failure, but also social marginalisation (Lockwood, 1997:96). Within a context of scarcity of resources, social marginalisation is an outcome of poverty, but also helps to reinforce poverty (ibid). In addition, Sen's concept of 'co-operative conflict' is useful in understanding the different conflicts of interest, 'entitlements' and bargaining power of individuals within the household, which results in intrahousehold inequalities (Sen, 1999:192). Due to economic pressures and greater conflicts of interest, accompanied by social marginalisation, the marriages and the households of the poor are likely to be more unstable than those of the rich narratives of home', Journal of Contemporary African Studies, 22 (1): 69-92. 
(Lockwood, 1997). This approach, which takes account of familial relationships and conflict within the household, will be used to analyse children's experiences of poverty and social marginalisation throughout this article.

It is clear that poverty severely constrains the family's ability to provide for their children and places great pressure on adult-child relationships within the family. Abject poverty affected the majority of the participants' households. Indeed, three quarters of the young people interviewed cited the family's inability to meet their basic needs as a major factor making them leave home. In over half of the homes I visited, poverty was a major constraint on the household's ability to care for the children.

In contrast to the harmonious and seemingly happy pictures drawn by school pupils of their family and home environment, the street children's drawings illustrated their experiences of poverty. Juma's (aged 14) drawing of himself at home (Figure 1) depicts himself with his mother and two younger siblings, all looking unhappy, with the words, "The whole family is hungry" (UCSC shelter, 17/4/00) (3). Amina wrote on her drawing, Figure 2, "We survive with difficulty. We sleep on the floor, we don't get any good food, other days we go to sleep hungry, we have problems surviving." Her drawing shows a girl bending over a washing tub with the words ' $I$ was washing clothes', on the other side of the house, a woman beats another, shown by long extended arms on the other woman's body, and underneath Amina wrote "she was beating me".

INSERT FIGURE 1 HERE WITH CAPTION: 
Figure 1: Juma's (aged 14) picture of himself at home: "The whole family is hungry" (UCSC shelter, $17 / 4 / 00)$.

Upendo, a 17 year old girl living at a centre for young women from disadvantaged backgrounds at the time of the interview, left home for town in order to help her relatives (3). This suggests that for some young people, leaving home for the street could represent an altruistic motive, in response to chronic poverty, to try to support the extended family. It also illustrates children's agency in constructing their social lives.

\section{INSERT FIGURE 2 HERE WITH CAPTION:}

Figure 2: Amina's (aged 14 years) drawing of herself at home: "I was washing clothes. She was beating me. We survive with difficulty. We sleep on the floor, we don't get any good food, other days we go to sleep hungry, we have problems surviving." (UCSC shelter, 31/3/00)

On a home visit with a 15 year old boy, Peter, whose father had died a long time ago, the chronic poverty facing some female-headed households was clearly evident, as this extract from my report of the home visit shows (3):

Peter's mother was not around and the neighbours did not know when she might return. They told us that she had a severe drinking problem and came and went at all hours. She did casual work, sweeping and cleaning anywhere she could for a minimal payment. The house consisted of a two-room traditional house (built out of mud and wood) with no furniture or a bed inside. Peter explained to us that the two younger children (aged 9 and 6, who, like Peter, were very small for their age due to sustained under-nourishment) 
stayed at home all day, and didn't have anything to eat in the morning or midday, just a little ugali [the staple diet, like stiff porridge, made from maize flour and water] or porridge in the evening if their mother earned some money and bought some flour. Peter's older brother (aged 19 and unemployed) helped to care for them and cooked for them, although Peter said he also treated them strictly, shouting and beating them. Peter and his younger brothers had never been to school. (Peter, home visit, 10/05/00)

During my later period of fieldwork, Peter, who lived at the residential centre and attended primary school, told me how he had gradually drifted to the street over a long period of time:

Peter and his friend used to go to town in the evenings to beg for food, and once were arrested and detained in a Remand Home for juvenile offenders for a month. When Peter returned home, he found out that his father had died many years ago, but his mother had kept this from him when he was younger. Peter was taken to live with his grandfather for a few years, where he grazed the cattle every day. He became seriously ill with TB, due to walking barefoot in the rain when grazing the cattle. His mother collected him and took him to hospital in Arusha, where his (maternal) aunt and uncle brought him milk and visited him regularly. His grandfather sold all his chickens to pay for his medical treatment. When nurses asked his mother, 'Is this your child?', she refused to acknowledge him as her son. 
When Peter had recovered, he went to live with his aunt, but she couldn't afford to send him to school because his uncle had recently died, and his aunt had six other children to support. He used to collect aluminium from the rubbish dump and sell it in town. He forgot where his mother and younger brothers lived, until one day he saw a cow, which he recognised as belonging to the family. He followed the cow across town to his mother's place, where he found his brother, although they did not recognise each other at first. Then he lived with his mother and brothers for a few months. Often his mother came home drunk late at night, or sometimes did not return at all. On one occasion, she was about to stab Peter with a knife, thinking he was an intruder, as she did not recognise him, until his brother called out to stop her. Peter's older brother helped cook and care for the younger boys. Peter used to go into town every day to beg for money, if he got 400 Tsh. [equivalent to 35 pence] he would go and buy fish to eat with the ugali [staple diet, made from maize flour] with his younger brothers. Gradually, Peter and his friend went into town more and more in the evenings, and would stay there overnight (fieldwork journal, 27/10/02).

Peter's account illustrates the process of transition from home to the street and how the chronic poverty experienced by his mother was passed on to her children, leading to increasing social marginalisation, in spite of assistance provided by the extended family. While the extended family could play an important role in fostering children of poorer relatives, who are unable or unwilling to care for them, during particular times of need in a child's life, Peter's account suggests that such support may only be available for temporary periods. 'Home', for Peter, was characterised by a lack of narratives of home', Journal of Contemporary African Studies, 22 (1): 69-92. 
food, clothing, opportunities for education, love or care, and indeed, familial ties with his alcoholic mother had already become tenuous long before Peter stayed on the street. Thus, spending longer and longer periods of the day on the street with a friend in search of food, appeared increasing attractive and preferable to staying at home. Indeed, UCSC project workers tried to mobilise the balozi [village leader] (5) to support the younger children in the household to attend school, as they were considered to be at high risk of becoming street children themselves.

Members of staff at all three street children projects involved in this study cited extreme poverty as a major factor causing children to leave home. However, many of the children's stories tell of other problems within the household which compounded their experiences of poverty, and triggered their decision to move to town. These factors will be explored in this section, against the background of the socio-economic context in Tanzania.

\section{Corporal punishment}

A key issue emerging from the children's interviews and home visits, which had a major influence on children's decision to run away from home, was adults' use of corporal punishment as a means of disciplining children. 69 per cent of the boys and girls who participated in individual interviews and 60 per cent of the children whose homes I visited cited 'being beaten' by adults as the immediate reason they left home. Many studies on education in Tanzania draw attention to the widespread use of corporal punishment as a means of disciplining children in school (UNICEF, 2001; Kuleana, 1999). Omari and Mbilinyi suggest that corporal punishment is enshrined in 
African culture and traditions: "Child rearing is always accompanied with spanking and stroke beating. It is an old and upheld cultural custom and belief that a child needs whipping in order to follow the instructions of the elders" (Omari and Mbilinyi, 1997:48).

Lachman comments on the problem of defining child abuse within the African context, since some of the activities carried out by children or directed to them are interwoven with African cultural traditions and customs, to the extent that when labelling them as child abuse one might be accused of interfering with people's culture and freedom (Lachman, cited in Omari and Mbilinyi, 1997:45). However, as Omari and Mbilinyi point out, "some people in the society, especially those who consider themselves as custodians of societal cultures, are blind towards the negative impact of what has been upheld by the previous generation and perceived as good" (Omari and Mbilinyi, 1997:45). Corporal punishment thus forms part of the cultural construction of childhood in Tanzania, and can be seen as a fundamental abuse of the adult-child power imbalance, which severely inhibits a continued dialogue between adults and young people, leading to young people's marginalisation from decision-making processes (ibid).

Project staff at the street children centre cited harsh punishments from parents as the first reason children leave home for the streets, in line with the children's own responses (UCSC shelter, 28/6/00). It is interesting to note that throughout the discussion with women at the community centre, the issue of corporal punishment was not mentioned, illustrating parents' lack of awareness about the negative impact narratives of home', Journal of Contemporary African Studies, 22 (1): 69-92. 
on children of corporal punishment and their perception that beating is an accepted form of disciplining children (Vocational Training Centre, 4/5/00).

The children participating in the study clearly demonstrated the overwhelmingly negative impact of physical abuse on young people. Most of the children said that they received corporal punishment from members of the immediate household mothers, fathers, step-parents, grandmothers, older brothers, aunts, uncles and cousins. In Emanuel's case, however, since his father had left home, his mother called upon an elder living in the village to discipline her son. This illustrates the notion discussed by Bekombo, according to African concepts of childhood, many people in the community can play the role of parents to a child (Bekombo, cited in UNICEF, 1999:115). Emanuel's story also reveals that corporal punishment is widely accepted as part of the cultural concept of 'childhood':

E: When I was at home, there was a mzee [an old man, an elder], mama used to call him, he comes and beats me, when he finished beating me, then I ran away and came here to town [...]. If I do wrong to my mum, she beats me and goes to call the elder who lives nearby, and he beats me.[...]

RE: What kind of mistakes did you make?

E: Perhaps, I was supposed to cut leaves or work on the field (Emanuel, UCSC shelter, 5/7/00) (4).

Over a third of the children's drawings of 'home' showed an adult beating a child, confirmed in the words they used to describe the picture. Figure 3 shows Daniel 
(aged 14) being beaten by his father (bottom left), with other members of the family (his mother, sister, younger sibling and brother).

\section{INSERT FIGURE 3 HERE WITH CAPTION:}

Figure 3: Daniel's drawing (aged 14 years) of himself (bottom left) at home: 'My family. My father canes me or twists my ear' (Daniel, UCSC shelter, 17/4/00)

Many of the children who cited physical abuse as the reason for leaving home came from very poor households. This suggests that there may be a link between poverty and corporal punishment. Poor households may be more likely to resort to physical violence to discipline children, due to the greater strains and anxieties, and conflicts of interest within these households.

In a few cases, boys ran away from home following involvement in theft from neighbours' homes to satisfy their basic needs, as Devi's story illustrates:

D: I ran away because my dad beat me. Then, I didn't sleep at home, I went to sleep at the top of the trees. When I'd stayed there for two days, on the third day, I left and went to town. [...] I went to the street children's centre there, I just stayed for a week, and was brought back home. I ran away again, I stole a big radio from some people's home, I blamed my father, and he was locked up, for two years, I accused him by saying that he had sent me to do it. When I'd accused him, he wanted to beat me, so I ran away fast, and came first to Arusha and I left. [...] I went home again, I found there was no-one there. When I didn't find anyone, I understood that my father must have gone away. 
[..] I just wanted to sell the radio to get some money for food. (Devi, UCSC residential centre, 16/7/00) (4)

This example raises issues about how parents can and should best respond to such misbehaviour. It also suggests that some children may run away from home to escape from trouble in the community, as well as within the family, that their own misdeeds have caused.

\section{The conflict between 'work' and 'play'}

African concepts of the reciprocal duties and responsibilities of children and their communities mean that children are seen as an important resource for the family and are expected to assist in a variety of productive and reproductive activities at the household level (Koda, 2000). However, as Koda notes, tensions around time use between parents and children begin to surface as soon as children express a preference for recreation (playing) rather than performing jobs assigned to them by adult family members (ibid: 249). The experience of several of the boys reflected this conflict between children and adults, as this interview with Michael, a small 17 year old boy staying at the UCSC shelter, shows:

RE: What was it like at home?

M: I used to be beaten by my father. When I came home from school, if I went to play football, I was beaten.

RE: Why? 
M: I was warned not to play football, dad refused to let me play football, and I ran away.

RE: Was there lots of work to do at home?

M: $\quad$ Yes, like fetching water, cultivating, chopping firewood.

RE: $\quad$ So dad said there wasn't time to play football?

M: $\quad$ Yes. $[\ldots]$

RE: Had you run away before that day?

M: No, I never ran away before.[...]

RE: What did you like about home?

M: At home, I liked going to school, I like playing, and growing crops.

RE: What didn't you like about home?

M: I didn't like being beaten, I didn't like having to carry heavy loads, like a bucket full of water from a river a little way away, I didn't like that.

RE: Did you have to do that every day?

M: Yes.

RE: What made you come to the streets?

M: Being beaten. I used to be beaten which is why I ran off, and came here to the streets.(Michael, UCSC shelter, 22/6/00) (4)

Michael depicted this tension in his drawing of 'home', (Figure 4) in which he portrays himself with a blank expression, carrying a large bucket of water, outside a house with three younger children playing nearby. In my later period of fieldwork, project staff told me that Michael had stayed at the UCSC residential centre, where he studied in Standard 5 at primary school for a year. Michael had been missing his parents, and asking to go home, but the UCSC project could not afford the bus fare for 
him to go home during the school holidays, since he came from a rural area far from Arusha. His father came looking for him, enquiring first at the UCSC shelter in town, and from there, was directed to the residential centre, having made the long journey from their home. Michael was very pleased to see his father, and after agreeing with staff members, Michael expressed his wish to live at home again, and they left together (fieldwork journal, 22/10/02). This shows that in spite of difficulties at home, some former street children actively choose to go back to their home communities once they have left and spent a considerable amount of time away from their families.

Two of the boys at the residential centre showed that they resented their parents' restrictions on their freedom. Devi wrote on his picture "There's no happiness, dad beats me, if, for example, I go for a walk and don't go back home, so I sleep in the trees" and Samuel wrote "I don't get any education, I'm not allowed to go for a walk in the village" (Devi and Samuel, UCSC residential centre, 28/4/00). Justin, a fourteen year old former street boy, also experienced conflict between his father's demands on his labour time to graze the cattle and his recreational desire to explore the outside environment.

\section{INSERT FIGURE 4 HERE WITH CAPTION:}

Figure 4: Michael's (aged 17) drawing of himself at home: "This is our home. This is me carrying water. I'm not happy because I'm beaten by my father if I play football. These are my younger brothers and sisters playing at home." (Michael, UCSC shelter, 17/4/00).

(C) Ruth Evans, 2004. Please cite as: Evans, R. (2004) 'Tanzanian childhoods: street children's narratives of home', Journal of Contemporary African Studies, 22 (1): 69-92. 
The experience of Charles, an eleven year old boy staying at the UCSC shelter, also illustrates the intergenerational tensions over time use and boys' recreational activities:

Charles' mother and brother came looking for Charles at the shelter, explaining that the father could not walk far, due to a physical impairment, otherwise he would have come himself. They told us that Charles had been severely punished by his father for going to watch videos in bars after school and returning late in the evening, over a period of several months. Charles had started absconding from school, disappearing for days at a time, and then returning home, where he would be beaten as punishment and taken to school to apologise to his teachers. He had finally run away to the street for a month, when he came to the UCSC shelter (fieldwork journal, March 2000).

During the months following his 'reintegration' into his family, Charles often spent a few days in town, or came to the UCSC shelter, complaining that his father or older brother had beaten him again, or simply coming to visit his friends and the teachers at the shelter. While the father's response to his son's behaviour was inappropriate and merely succeeded in pushing his son further away, the father did seem to genuinely care about his son, as did the rest of the family - his mother, brothers and sisters, and his elderly grandfather. Charles' habit of returning home late and neglecting his agricultural tasks was irresponsible, in view of the economic pressures facing the household. This example clearly illustrates the strain on adult-child relationships within the family caused by the economic situation and national levels of poverty in Tanzania. In this case, these pressures were likely to be further aggravated by the narratives of home', Journal of Contemporary African Studies, 22 (1): 69-92. 
father's physical impairment and his frustration and sense of inadequacy in not being able to provide for the household.

On a later visit to Arusha, I visited Charles's home in one of the poorer districts of town, and was pleased to find that he seemed happy living at home. He proudly showed me all of his school books and his father confirmed that he was progressing well at school. One boy at the shelter mentioned that it was Charles who had befriended him on the streets and brought him to the UCSC shelter, where he had stayed for the past three months, while Charles had returned home (fieldwork journal, 2/2/01). Thus, it appeared that Charles maintained fluid ties with his friends both on the streets and at the UCSC shelter. The street represented a place where he could escape from corporal punishment, should he need to, when tensions with his father surfaced around the need for his labour on the farm and his own recreational pursuits.

Having discussed key impacts of the cultural construction of childhood on children's experiences of 'home', the next sections explore how diverse household structures affect children's socio-economic position within the household and wider community.

\section{Household structures}

African concepts of childhood mean that rights over children are vested in men by customary, religious and statutory law so that in the event of divorce, separation or husband's death, the custody of children remains with the father or his clan members (UNICEF, 1999:47). Indeed, it has been suggested that the rights of the child can only be understood fully in the context of the status of the child's mother, since 
"women are effectively the property of men and the children they bear also 'belong' to their fathers" (Omari and Mbilinyi, 1997:19). Thus, the structure of the household and the legal status of the parents' marriage has a considerable impact on the socioeconomic position of children. Tanzanian society is characterised by considerable diversity of household structures, kinship responsibilities and a tradition of child fosterage within the extended family (Creighton and Omari, 1995; Koda, 2000). Thus, it seems important to analyse children's experiences of 'home' in terms of the diverse household structures which form the core of their social networks, and the implications of their position within such structures for the children concerned.

\section{Female-headed households}

Omari notes that the 1988 Census estimated that 30 per cent of households in Tanzania consist of a single (mainly female) parent, and that female-headed households are more common in urban than in rural areas, because women in towns work mainly in the informal sector and are thus economically independent (Omari, 1995:215). Positive aspects of female-headed households may include: women are less constrained by patriarchal authority at the domestic level, have greater freedom to take on paid work, enhanced control over finances and a reduction or absence of physical and/ or emotional abuse (BRIDGE, 2001:3). In addition, studies have shown that the expenditure patterns of female-headed households are more biased towards nutrition and education than those of male households (ibid). However, femaleheaded households may face greater difficulties than men in gaining access to labour markets, credit, housing and basic services, and there may be additional layers of discrimination against female heads (ibid). Furthermore, single parent households, 
most of which are female-headed, also face the difficulties of one adult having to combine income-earning with household management and child care, with the result that the parent can only take on part-time, informal jobs with low earnings (ibid).

In Tanzania, female-dominated activities in the informal sector include beer brewing, mama ntilie - small eating places selling cooked food (most of which are mobile to follow customers), selling doughnuts, peanuts, ice lollies, gardening, poultry keeping, pig keeping and selling charcoal and firewood (Koda, 1995:147). Female microentrepreneurs have very little access to credit due to the small nature of their ventures, lack of property rights and inability to generate savings (ibid). As Koda comments, the customs of most ethnic groups in Tanzania oppose women having either inheritance or ownership rights over land and other immovable property, the very items which are usually demanded as collateral for bank loans (ibid).

In the light of these gender inequalities, and the idea that the rights of the child are largely dependent on the status of the child's mother, female-headed households in Tanzania would thus appear to be particularly vulnerable to poverty and insecurity, with adverse consequences for children within the household. Although a link between female headship and poverty cannot be assumed (BRIDGE, 2001), the young people involved in this study, whose mothers were separated from their fathers, whose fathers had died, or who had never known their fathers, who lived in female-headed households, all commented that their home life was characterised by impoverishment, as the case of Peter (discussed earlier) illustrates. Two other home visits revealed the problem of irresponsible paternity, where single mothers were left to bear the costs of bringing up children born outside of marriage on their own. narratives of home', Journal of Contemporary African Studies, 22 (1): 69-92. 


\section{Step-parents}

In view of female-headed households' vulnerability to poverty and instability, due to their lack of independent access to land and property, many women find another partner to live with. However, due to the notion that children 'belong' to their fathers, step-fathers are not expected to care for older children from previous marriages. This was revealed in three home visits, and in two of the children's interviews.

Whereas step-fathers are not expected to look after step-children, men who remarry often expect their new wives to care for children from their first marriage, since the children are considered to 'belong' to their father. One of the clearest messages emerging from the children's interviews, discussions, and drawings, is that boys are particularly at risk of abuse, neglect and harassment from step-mothers who resent the inheritance rights they have over their own children.

In the focus group discussion with the boys at the UCSC shelter, the problem of stepmothers was cited as the main reason boys run away from home (UCSC shelter, 17/4/00). They claimed that they are beaten severely if, for example, they are carrying the baby and it falls, they are made to go without food, not allowed to go to school and made to do hard labour at home. Step-mothers' neglect and exploitation of their step-sons was also reflected in Samson's drawing of 'home' in which he depicted himself, his father, step-mother and younger brother, and wrote, "my stepmother treats me badly, I feel hungry" (Samson, UCSC shelter, 17/4/00). While step-

mothers' ill-treatment of boys seems to be a gender-specific abuse of children's rights, 
due to the threat step-sons represent to the inheritance of the husband's property, it can also be seen as a product of structural gender inequalities, which deny women independent access to land and property, and overburden them with productive and reproductive work.

An issue resulting from the breakdown of a first marriage and re-marriage, is that as well as step-mothers' ill-treatment, children from previous marriages may also experience resentment and rejection from their father. As noted earlier, the rights of the child can only be understood fully in the context of the status of the child's mother (Omari and Mbilinyi, 1997). As Bledsoe argues, for formally or informally polygynous men, there is a tendency to rank wives, and therefore children by wives' status (Bledsoe, cited in Lockwood, 1997:94). Consequently, children of high-status wives, and especially educated wives, may receive special attention, while those of uneducated, low status wives may be marginalised (ibid). As Lockwood notes, this relates to a long-observed approach to paternity in African societies in which it is social, not biological paternity which is important, and that people may choose courses of action to emphasise or de-emphasise particular relationships at particular times (ibid). Thus, when husbands reject and banish their first wife, the children from that marriage are often rejected, as the experiences of two of the street boys interviewed shows.

Emanuel, a 17 year old boy staying at the UCSC shelter at the time of the first interview, explained that he used to live with his mother, but he ran away due to physical abuse. Staff told me that Emanuel's father had rejected his first wife, who was disabled, and Emanuel, leaving them without any property, and had married narratives of home', Journal of Contemporary African Studies, 22 (1): 69-92. 
another woman with whom he had fathered other children (fieldwork journal, 5/7/02). Emanuel's father found him on the streets and took him to his house where he beat him. After staying for a week, Emanuel came back to the UCSC shelter:

E: I stayed and then that step-mother came and took me away with her child, they came to take me. I found that she gave me work, but she didn't give the others any work, but me, she gave me work to do. I refused and ran away to town. Yes, then I came here for the second time, I stayed and my father came, he knew I was here. He left me alone. And then the priest from our church came here. He came to see me. And now I'm here. My father used to hate me and he threw my clothes, he threw my clothes down the toilet, he dropped them into the pit.

RE: Why do you think he did that?

E: I don't know, he just loves the children from that other woman. She has six children.

At the end of the interview, Emanuel stressed the ill treatment he had experienced from his step-mother. His labour was exploited while her children received preferential treatment and attended school: "It was me who had to do all the work, while her children went to school, when they came back they ate their meal, then other food was prepared which I ate, they would go to watch TV, and tell me to finish the other work first". (Emanuel, UCSC shelter, 5/7/00) (4).

When I talked to Emanuel again during my fieldwork over two years later, Emanuel was upset that his father still refused to have any contact with him, or his mother, and narratives of home', Journal of Contemporary African Studies, 22 (1): 69-92. 
expressed his wish that UCSC staff would facilitate a reconciliation with his father, since on his own, he felt powerless and afraid to approach him. Emanuel's story reveals the particularly vulnerable situation of women and children who are rejected by an autocratic father/husband, due to preferential treatment for a second wife and her children, leaving them with no rights to property or inheritance. Emanuel experienced such rejection and hatred by his father as a source of unresolved sadness and pain. As Cornwall notes:

Refusing to acknowledge paternity is a well-used tactic to avert having to cater for a child, or maintain any kind of link with its mother...Becoming a father is an expected part of men's life courses, yet despite being 'owners' of children, fathers can devolve responsibility over their children onto other women, either their mothers or their kin; sometimes to the extent whereby they become practically irrelevant in the day-to-day process of bringing up the child. (Cornwall, cited in Lockwood, 1997: 94)

The experiences of Juma, a fourteen year old living at the UCSC shelter, whose younger brother also lived on the streets, also illustrate the strategy adopted by some men to de-emphasise a relationship with a lower ranking wife, and marginalise the wife and her children. Juma expressed his problems at home in terms of a lack of love on the part of his father, step-mother and their children, while his real mother was unable to provide for him:

RE: When do you feel happiest? narratives of home', Journal of Contemporary African Studies, 22 (1): 69-92. 
J: $\quad$ Soon I'll be grown up, so I won't be happy because of my parents, my father doesn't love me and my mother lives in a place where there are a lot of problems, so I can't feel happy. [...] UCSC took me home and I went to school at my step-mother's place, but I couldn't cope because my step-mother doesn't like me and my father doesn't love me and their children too don't like me, and they say I'm waiting for my father to die, so that I get the inheritance. I saw that there was no love there, and left. [...] I would like to go to school anywhere they [UCSC] decide, but not at my step-mother's. And I can't stay with my real mother because she only has one rented room and is a petty trader at the market (Juma, UCSC shelter, 20/4/00) (4).

According to UCSC members of staff who visited Juma's home, Juma's 'father' had four wives, two of whom had left him (including Juma's mother) and 23 children. When I talked to Juma again over two years later, he took me to meet his mother who rented a room in a traditional house in town, where she lived with his younger brother. She relied on going around town selling spinach, which she bought at the market, for her livelihood. Juma and his mother described how Juma's father had rejected her, and she had been pushed over by one of her husband's other wives, who had broken her arm and hurt her leg, and driven her away. An older sister had got together enough money for the bus fare for her mother to go to Arusha with her youngest son, where she stayed with her eldest son, who helped her pay the rent. Juma stayed behind with his younger brother, as they were both studying in Standard 4 at primary school, while Juma continued working as a day labourer on a coffee plantation as soon as he got home from school every day. narratives of home', Journal of Contemporary African Studies, 22 (1): 69-92. 
Juma's mother explained that she was not officially married to Juma's father, which meant that she was not ranked as highly as his other wives and children. Juma's mother was in a vulnerable position, as a woman involved in an informal union with a man who had fathered her children. Thus, when Juma's father chose to de-emphasise the relationship, due to demands on scarce resources, tensions, and conflicts of interests with his other more favoured wives and children, Juma's mother and her children were marginalised. As Lockwood notes: "The unequal economic and ideological ability of men and women to manage relationships makes women potentially more vulnerable to marginalisation than men.” (Lockwood, 1997:98)

Although staying with the village balozi (5) leader seemed at first to offer an alternative means of support to enable Juma to attend school, he was again marginalised within this household, while the other children received preferential treatment:

I suffered there, my father rejected me, so I stayed with the balozi (5) [village leader], I studied there. Then after a while, his children went to school, but I was told to stay at home and graze the cattle. I stayed and suffered, my stepmother doesn't love me, I was lonely, the others went to school but I couldn't. So then I decided to come to Arusha, I ran away to Arusha. (Juma, UCSC shelter, 4/12/02) (4)

Juma's story illustrates how a child's situation is clearly linked to the status of the child's mother, and a husband's rejection of a wife often leads to insecurity and impoverishment, with particularly detrimental impacts on children. narratives of home', Journal of Contemporary African Studies, 22 (1): 69-92. 


\section{Polygamous households}

A significant proportion of marriages in Tanzania are polygamous (28 per cent of married women have co-wives: Omari, 1995), which has important implications for the welfare and status of children within polygamous household structures. Koda suggests that the father's role in socialising children is greatly curtailed in polygamous households: "With limited time, and love and responsibilities shared among several children, most polygamous fathers fail to have a dialogue with their children" (Koda, 2000:245). She suggests that this corresponds to the 'autocratic' (the father dictates to the others) mode of decision-making (ibid). However, each wife in a polygamous household also has a degree of autonomy in relation to decision-making about food production and other matters concerning resources and welfare for herself and her children (Omari, 1995; Koda, 2000). Omari asserts that decision-making in polygamous households involves negotiations and the balancing of interests of several wives and their offspring, with elements of tension and jealousy sometimes arising between wives and children, as was illustrated in the example of Juma (see above) (Omari, 1995:211).

Polygamy was cited by UCSC members of staff as a factor making children run away from home, since the current economic situation places greater pressure on large families and husbands are no longer able to provide for several wives and their many children (UCSC shelter, 28/6/00). Three of the young people participating in the study came from polygamous families. Lucy saw her father's polygamous household 
structure as a form of security and wealth when her mother could no longer provide for her:

At home, because my father had several wives, when I finished Standard 7 [primary school], I decided to go and find him, he used to live in Shinyanga. We arranged it with my mother, and she got the bus fare for me. I stayed for eight months, then my father started to be sick. After four days, he died and we brought him to Moshi to be buried, and when the mourning period was over, everyone went their own way, the other wives just went to their fathers, that's all, there were many children. Then I saw that my mother didn't have any help and I thought I'll come to Arusha and look for work (Lucy, Theresa House, 20/5/00) (4).

On the death of Lucy's father, however, the wives were forced to return to their parental homes with their children, causing the break-up of the polygamous household. The wives and their children were therefore left in a vulnerable position, with few, if any, inheritance rights. Lucy's move to the streets, as in the example of Upendo, was thus motivated by an altruistic desire to earn money to help her mother, in response to poverty.

Justin's father's polygamous household also seemed to be relatively wealthy in terms of assets and food security. In response to the question, "What was it like at home?", Justin replied, "My father used to beat me, that's why I came here. It was when I went to graze the cows and if they ate people's maize, he came and beat me" (Justin, UCSC shelter, 3/5/00). Two of Justin's older brothers had come to the UCSC shelter narratives of home', Journal of Contemporary African Studies, 22 (1): 69-92. 
looking for Justin, saying that he had run away from home several times before, but they usually managed to bring him back. According to his brothers, Justin used to abscond from school, saying he would rather graze the cattle than go to school, but he would wander off, leaving the cattle to ruin people's crops, and then he would be beaten severely by his father. Justin refused to go back with his brothers, fearing his father's punishment.

Despite responding inappropriately to Justin's misbehaviour, the father appeared genuinely concerned about his son, and in view of the financial pressures on such a large household and the need for all the children to contribute to the family labour, the father's frustration at his son's irresponsible behaviour is understandable. Apart from the occasional harsh punishments, Justin seemed happy at home, enjoying the company and support of his large family:

RE: Do you feel happy at home?

J: Yes.

RE: At home, who/where would you go to play?

J: With friends, my younger brothers and sisters, there are lots of us, same father but different mothers.

RE: Who/ where would you go to share a secret?

J: $\quad$ My father or mother or friends.

RE: Who/where would you go if you get bad news?

J: $\quad$ I can tell my father or my mother.

RE: Who/where would you go if you are beaten by your mates?

$\mathrm{J}$ I $\quad$ I tell my father or my mother or my step-mother. narratives of home', Journal of Contemporary African Studies, 22 (1): 69-92. 
RE: Who/ where would you go if you are beaten by an adult?

J: $\quad$ For example, if it's my father, I would go to my maternal uncle (Justin, UCSC shelter, 3/5/00) (4).

Many of the other children interviewed did not respond nearly as positively to these questions, implying that fewer adult figures were available to turn to for support in non-polygamous household structures. Thus, in Justin's experience, although his father expressed his 'autocrat' role through the threat and fear of violence as a means of exerting control over the household, the polygamous family structure could also represent a source of support.

During my later period of fieldwork over two years later, I heard that after staying at the UCSC residential centre for a year, where he was studying in Standard 3, Justin had returned home for his circumcision and initiation rites, and had decided to stay at home. His father gave him a field where he cultivated his own maize, he slept in his own hut, now that he was a moran [warrior - term used for circumcised Maasai young men], and was building his own more permanent hut just outside his father's compound, which he proudly showed me. His father was pleased that Justin was living at home again, but was clearly finding it a strain on the household's resources to meet all the needs of his twenty or more children. Justin's case suggests that polygamous households could offer young people, particularly young men, a source of support and sense of belonging, as well as valuable assets such as land and property. However, sharing the household's resources between so many wives and children clearly had detrimental impacts on children, particularly on their ability to access education. narratives of home', Journal of Contemporary African Studies, 22 (1): 69-92. 


\section{Family breakdown}

Using Sen's concept of the different conflicts of interests amongst individuals within households, and men, women and children's different entitlements and bargaining power, the likelihood of tension and conflict within poor households seems greater (Sen, 1999). Thus, as Lockwood points out, the marriages and the households of the poor are likely to be more unstable than those of the rich (Lockwood, 1997). In some cases, this leads to the breakdown of the family and the dispersal of the household.

Several of the former street children came from households which had dispersed on the death of one or both of the parents. As the impacts of the AIDS epidemic are increasingly being felt, the numbers of orphaned children at risk of turning to the informal sector on the street to support themselves is accelerating, as families and communities are either unable, or unwilling, to support them. Several other street children came from families where the parents' marriage had broken up and the members of the household had dispersed, to stay either with relatives or friends in temporary or more permanent arrangements, or on the street.

The story of Nixon, a seventeen year old living at the UCSC residential centre who was head boy at primary school, reveals how relations between family members in poor households can become strained, eventually leading to the disintegration of the household. A combination of poverty, corporal punishment at school (due to lack of school fees), his father's alcoholism and domestic violence made Nixon drop out of school and engage in petty theft, eventually leaving for the streets: 
$\mathrm{N}$ : I ran away from home because when I was studying in Standard 2 at home when I was in Standard 1, my father didn't pay the school fees for me because he was an alcoholic and he didn't have any work. If he did casual work, when he was paid, he got drunk, when he came back home, he beat all of us and my mum and he threw us out, we went to sleep at the neighbours' place. If we came back in the morning, we would sit outside until he decided to get up, then I changed my clothes and went to school. You would also find that he had eaten all the food. At school, I used to be beaten and suspended because of the school fees, but I put up with it. When I reached Standard 2 I couldn't bear it anymore, and I went back home, and I didn't go to school. He used to give me work to do, when I didn't do it, he beat me and told me to go to school. If I asked him for school fees, he said, 'Just go as you are, how the hell did you used to go to school without school fees before?' I saw that things weren't cool there and went to my grandmother's, and helped her so that she would give me school fees.

'Then there was a friend of mine, my cousin, and he didn't used to go to school because he was retarded and he used to smoke a lot of marijuana. Once he convinced me to break into a kiosk and I agreed. He broke in and stole things and came out with them and money. We went to town with the things and we sold them, with the money we bought radios. We returned to my grandmother again. When evening came, we found that my (maternal) uncle had already reported it to the police, he thought we were the thieves. 
We just sat there scared and he came and found us with the radios. He asked us and we didn't answer, so he knew it must have been us that broke into the kiosk, and he took us to the village council office, we were just counselled and we came back home, but my uncle held a grudge. Another time, that friend of mine stole grandma's coffee plants, and at night we were both caught, and we were beaten from $10 \mathrm{pm}$ to $12 \mathrm{am}$. We were beaten by my older brother and that uncle. We were beaten, and allowed to rest, then beaten again and allowed to rest, but I wasn't guilty. When I came away from there, I saw that I didn't have anywhere to live. If I stayed with grandma I was beaten, if I went home, I was beaten, so I decided to go to town. [...] That was in 1993. I lived on the streets and my parents didn't look for me, so I just got used to it. (Nixon, UCSC residential centre, 16/07/00) (5).

Nixon told me that when he had gone to visit 'home' in the school holidays, his father had reported that Nixon's mother, younger siblings and older brothers had all left home for town, where they survived by begging, or picking pockets. Another older brother was working in the mines. Thus, the combination of poverty, the father's alcoholism and domestic violence sadly drove Nixon's mother and all their children to the streets, causing the household to disintegrate. When I talked to Nixon during my fieldwork over two years later, he told me that he was one of 20 pupils chosen from 120 in his year to go to the government secondary school, and UCSC had found a sponsor to meet the costs of his secondary education. His younger sister, who was on the streets at the time of the initial interview, was being sponsored and was studying in Standard 6 at boarding school. 
Nixon's account illustrates the vulnerable position of children following the break up of their parents' marriage and disintegration of the household, and shows that residential centres such as UCSC may offer the most appropriate form of care for some children, for whom 'home' is simply not an option. Following extensive periods on the street, both Nixon and his younger sister Maua, had taken up the opportunities for education that UCSC could offer them. Residential care at the UCSC centre had enabled Nixon to flourish academically, both at primary school, where he was head prefect, and at secondary school. This illustrates children's resilience in the face of adversity, and supports the findings of a UNICEF study in Tanzania, which suggested that running away from home to become a street child can be a strategy for obtaining educational opportunities, quite apart from access to other basic needs, such as food and shelter (UNICEF, 1999: 272).

\section{Rural-urban migration}

While most of the young participants' experiences have been explored under the themes already discussed, some of the children's experiences of home defy attempts at categorisation, revealing the diversity of children who become street children and their own agency in constructing their social lives. The experiences of two boys participating in the study suggested that some street children come from more comfortable home environments, and the children themselves find it difficult to rationalise why they left home. This perhaps suggests that the attractions of urban lifestyles may exert a significant force in young people's decision to migrate to towns and cities. Furthermore, the opportunities for earning a cash income and urban lifestyles, which traditionally attracted young men to migrate to African towns and 
cities, are likely to make it difficult for young people to re-adjust to a predominantly rural lifestyle at home. One of the groups of boys participating in focus groups conducted with primary school pupils also articulated this sense that town life was 'easier' and, thus, more appealing than village life, which involved hard agricultural labour. Thus, the perception that large towns and cities offer wealth and employment opportunities still seems to be pervasive among young people, particularly boys. This was also evidenced by the large rural-urban influx to Arusha town from neighbouring regions, which contributes to its high annual population growth rate of 6 per cent, compared to the national average of 2.8 per cent (Kadonya et al, 2002:13).

\section{Conclusion}

Street children's experiences of 'home' suggest that chronic poverty, and the accompanying social marginalisation, is a major influence in children's decision to leave home. Leaving home to earn some money to help support the family was an altruistic motive adopted by some children, in response to poverty. However, chronic poverty experienced at home was usually compounded by negative manifestations of the cultural construct of childhood, which triggered children's decision to leave. Socio-cultural expectations of children's responsibilities in contributing to the household's productive and reproductive activities caused tensions between the generations around time use. Several boys experienced conflict with their parents over their recreational needs and the duties they were expected to perform. Corporal punishment was shown to represent an integral part of the cultural construction of childhood in Tanzania, which was experienced as overwhelmingly negative by the boys and girls participating in the study. Adults, however, seemed unaware of the narratives of home', Journal of Contemporary African Studies, 22 (1): 69-92. 
negative impacts of their actions and resistant to change. There was some evidence of a link between poverty and corporal punishment - poor households may be more likely to resort to physical violence to discipline children, due to the greater strains, anxieties and conflicts of interest within these households. The young people's accounts suggest that corporal punishment subordinates children and severely inhibits a continued dialogue between adults and young people, marginalising them from decision-making at the level of the household, school and community.

Some boys from poor households misbehaved, were irresponsible in their agricultural duties, or engaged in theft from neighbours in the community, which parents and other relatives responded to with corporal punishment, which triggered the boys' move to the street. This suggests that some children may run away from home to escape from the trouble, in the community as well as in the family, that their own misdeeds have caused. This also raises issues about how parents can, and should, respond to such misbehaviour.

Female-headed households appear particularly vulnerable to impoverishment and insecurity, with negative consequences for the children within the household. Children whose mothers remarried experienced rejection from their mother and stepfather, since according to custom, step-fathers are not expected to provide for older children from their wife's first marriage. Step-mothers, in the boys' experience, often subjected boys to harassment, neglect, physical and verbal abuse and exploited their labour, due to resentment and jealousy of boys' inheritance rights to their father's property over their own children. The experiences of some former street boys illustrated the notion that it is 'social' rather than 'biological' paternity which is narratives of home', Journal of Contemporary African Studies, 22 (1): 69-92. 
important within African societies. In particular, some men, particularly those involved in polygynous relationships, were shown to emphasise or de-emphasise particular relationships at particular times, resulting in the rejection, impoverishment and marginalisation of women and their children. Children's experiences of polygamous household structures revealed the economic pressures facing 'autocratic' father figures, but also suggested that the large polygamous family could be seen as a source of support and company. In some cases, the economic pressures, domestic violence and conflict of interest within poor households caused the breakdown of the family, and the household dispersed, with children leaving home for the street.

This article has therefore shown that a complex myriad of factors influence children's decisions to leave home, and that children are very often making a rational choice of one lifestyle over another. Chronic poverty, social marginalisation, young people's subordination within diverse household structures, and underlying gender inequalities therefore represent the key motivating forces influencing Tanzanian children's decision to leave home for the streets of urban areas. In response to difficult home situations, children leave their immediate household, and seek their own independent life on the streets, where they construct their own social networks amongst their peers and other members of the community. However, some street children's experiences of home defy attempts at categorisation, revealing the diversity of children who become street children, and their own agency in constructing their social lives. For some young people, the attraction of an 'easy life' in town and urban employment opportunities exert a significant force in their lives, leading to their rejection of rural livelihoods at home on the farm. narratives of home', Journal of Contemporary African Studies, 22 (1): 69-92. 


\section{Endnotes}

1. The term 'street children' is in itself problematic, since it sets up a dichotomy between children who use the street to live and work, and 'normal' children who live at home. However, the term is used here to discuss the particular situation of children and young people who live independently on the street, supporting themselves, largely without adult supervision.

2. Based on findings from ethnographic research I conducted with street children, while working as a volunteer at Urafiki Centre for Street Children (UCSC - the name has been changed) in Arusha, Tanzania 1999-2000, and a further period of fieldwork in 2002. A child-focused participatory methodology was undertaken, paying attention to gender and age differentials. Semi- structured individual interviews and focus group discussions were conducted in Swahili with girls and boys on the streets and at the centre, focus groups with primary school pupils, and with staff at local nongovernmental organisations working with street children. Home visits to come of the children's families in the region were also combined with participant observation and participatory techniques with the children, such as drawings and photographic representation of their lives on the street. The research was conducted in accordance with the ethical guidelines of the Social Research Association (see: www.thesra.org.uk).

3. In the interests of confidentiality, the names of the children and the names of the non-governmental organisations working with children in Arusha have been changed. 4. Translated from Swahili transcripts of tape-recorded semi-structured interviews and focus groups conducted with street children, as part of the fieldwork (see note 2). 
5. Balozi - a village leader of ten households at the local political level, within the structure of the ruling CCM party [Revolutionary Party].

\section{References}

Baker, R. and Panter-Brick, C. 2000. “A comparative perspective on children's "careers" and abandonment in Nepal". In C. Panter-Brick and M. Smith (eds.), Abandoned Children, Cambridge: Cambridge University Press, 161-180

Bendera, S. 1999. "Promoting Education for Girls in Tanzania". In C. Heward and S. Bunwaree (eds.), Gender, Education and Development: Beyond Access to Empowerment, London: Zed Books Ltd.:117-132

BRIDGE 2001. "Briefing paper on the 'feminisation of poverty' "., Report No. 59, Brighton: Institute of Development Studies

Creighton, C. and Omari, C. (eds.) 1995. Gender, Family and Household in Tanzania, Aldershot: Avebury

Green, D. 1998. Hidden Lives: Voices of Children in Latin America and the

Caribbean, London: Save the Children Fund

Hulme, D., and Shepherd, A. 2003. "Conceptualizing Chronic Poverty”, World

Development, 31, 3:403-423

James, A. and Prout, A., (eds.) 1997. Constructing and Reconstructing Childhood, London: Falmer Press

Kadonya, C., Madihi, M., and Mtwana S. 2002. Tanzania Child Labour in the

Informal Sector: A Rapid Assessment, Geneva: International Labour Organisation, International Programme on the Eliminiation of Child Labour Koda, B.O. 2000. "Democratisation of social relations at the household level: The participation of children and youth in Tanzania". In C. Creighton and C.K. Omari narratives of home', Journal of Contemporary African Studies, 22 (1): 69-92. 
(eds.) Gender, Family and Work in Tanzania, Ashgate: 237-265 Koda, B.O. 1995.

"The economic organization of the household in contemporary Tanzania". In C.

Creighton and C.K. Omari (eds.) Gender, Family and Household in Tanzania: 139155

Kuleana Center for Children's Rights (1999) The State of Education in TanzaniaCrisis and Opportunity, Kuleana, Mwanza

Lockwood, M. 1997. "Reproduction and Poverty in Sub-Saharan Africa", Tactics and Trade-Offs: Revisiting the links between gender and poverty, IDS Bulletin, 28(3): 91-100

Mufune, P. 2000. "Street youth in southern Africa", International Social Science

Journal, 52, 164: 233-243

Omari, C.K. 1995. "Decision-making and the household: case studies from Tanzania" in C. Creighton and C.K. Omari (eds.), Gender, Family and Household in Tanzania, 203-220

Omari, C.K. and Mbilinyi, S. 1997. African Values and Child Rights: some cases from Tanzania, Dar es Salaam, DUP

Sen, A. 1999. Development as Freedom, Oxford: Oxford University Press

UNICEF 2001. Situation Analysis of Children in Tanzania, Dar es Salaam, UNICEF

UNICEF 1999. Children in Need of Special Protection Measures: a Tanzanian case study, Dar es Salaam: UNICEF

Veale, A., Taylor, M. and Linehan, C. 2000. "Psychological perspectives of 'abandoned' and 'abandoning' street children” in C. Panter-Brick and M. Smith (eds.), Abandoned Children, 131-145

(C) Ruth Evans, 2004. Please cite as: Evans, R. (2004) 'Tanzanian childhoods: street children's narratives of home', Journal of Contemporary African Studies, 22 (1): 69-92. 
Figures to be inserted as indicated in the text of Ruth Evans' article, Tanzanian

Childhoods: Street Children's Narratives of 'Home'

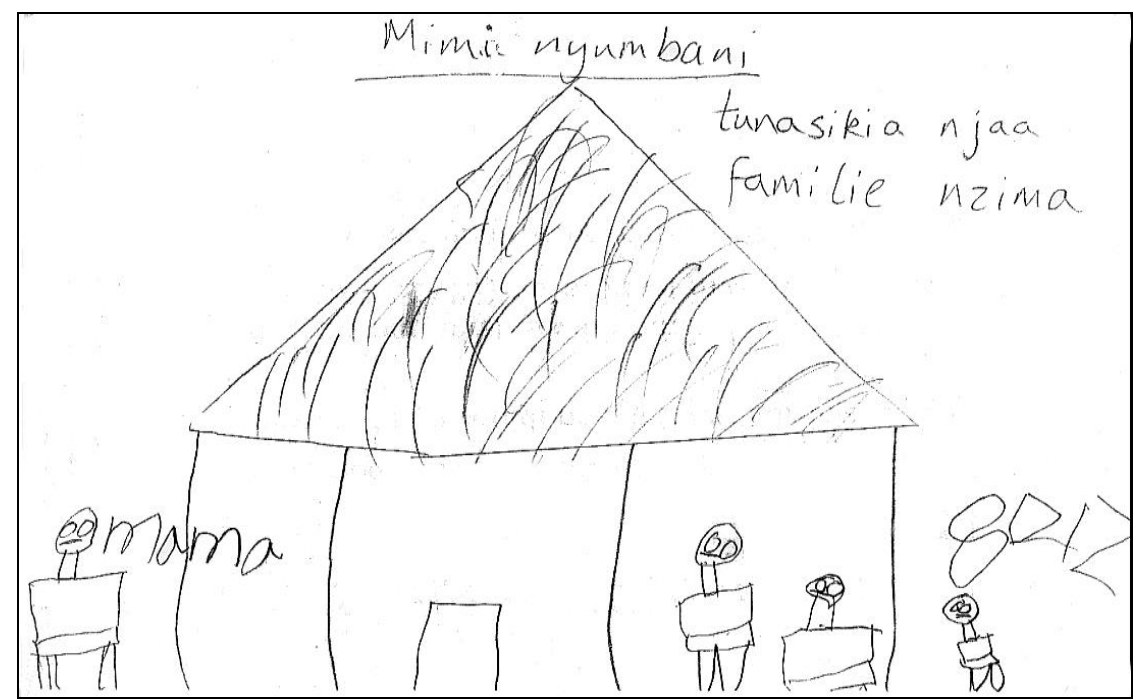

Figure 1: Juma's (aged 14) picture of himself at home: "The whole family is hungry" (UCSC shelter, 17/4/00).

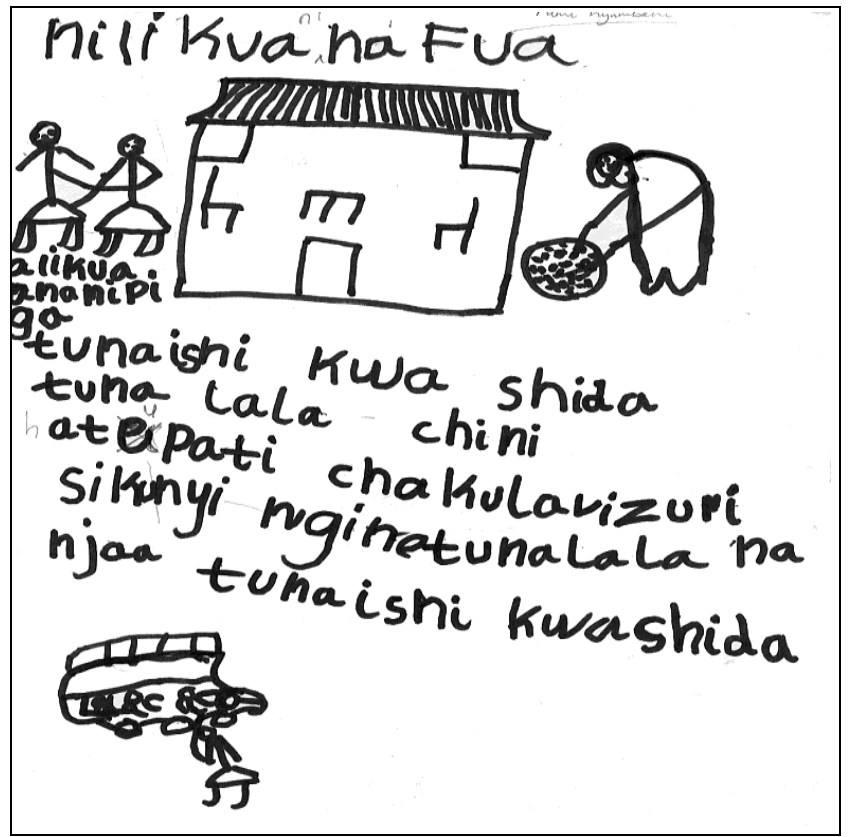

Figure 2: Amina's (aged 14 years) drawing of herself at home: "I was washing clothes. She was beating me. We survive with difficulty. We sleep on the floor, we don't get any good food, other days we go to sleep hungry, we have problems surviving." (UCSC shelter, 31/3/00) narratives of home', Journal of Contemporary African Studies, 22 (1): 69-92. 


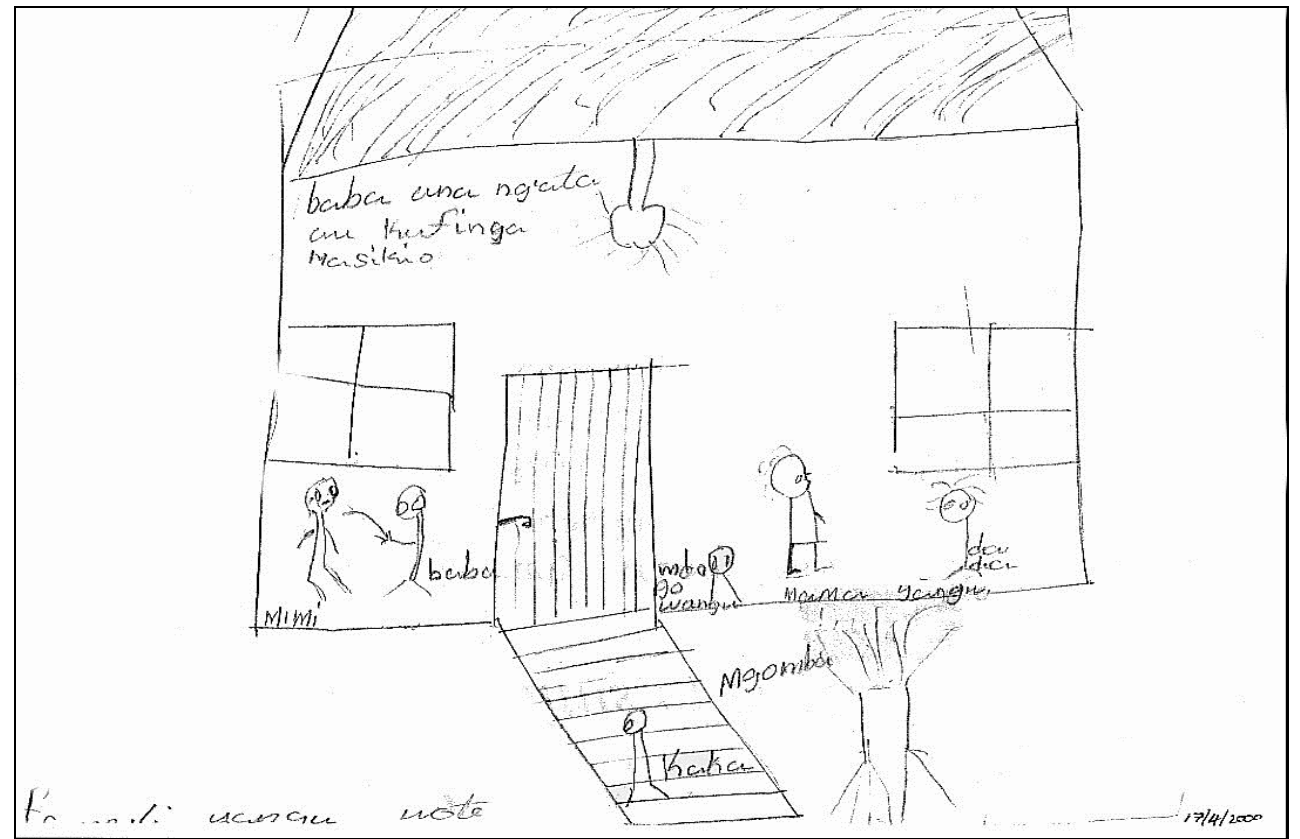

Figure 3: Daniel's drawing (aged 14 years) of himself (bottom left) at home: 'My family. My father canes me or twists my ear' (Daniel, UCSC shelter, 17/4/00)

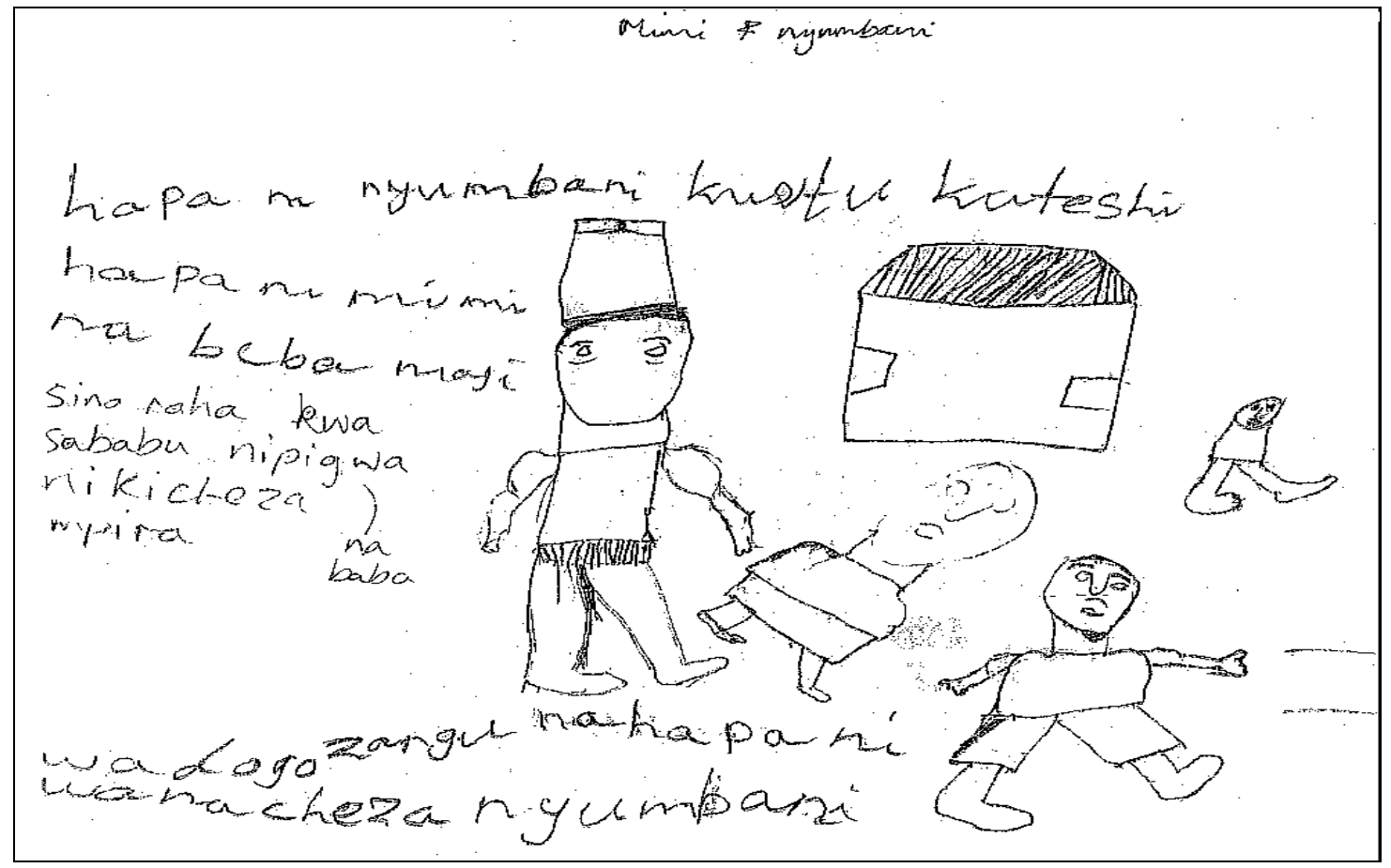

Figure 4: Michael's (aged 17) drawing of himself at home: "This is our home. This is me carrying water. I'm not happy because I'm beaten by my father if I play football. These are my younger brothers and sisters playing at home." (Michael, UCSC shelter, 17/4/00). narratives of home', Journal of Contemporary African Studies, 22 (1): 69-92. 